\title{
IMPACT OF TRAINING, CUSTOMER ORIENTATION AND SUPERVISORY BEHAVIOR ON SALES PERFORMANCE
}

\begin{abstract}
Azeem Khan
ABSTRACT

This study examined the effect of Training, Customer Orientation and Supervisory Behavior on Salesforce Performance in the context of small and medium-sized companies (SMEs). The diffusion of technology, such as customer relationship management (CRM) systems and social media, has created a need to improve the understanding of how to manage interactions with customers in today's digital era. The importance of technology is raised in term of social media and as the world is treated as the "global village'. More importantly beginning of novelties such as cloud computing and webbased technology safe time and human efforts. The term sales performance is the key to success for many organizations and treated as most demanding topic for firms. For this study, three hypotheses were formulated and tested with the help of Pearson correlation by using SPSS. Findings indicate that all the Training, Customer Orientation and supervisory behavioral dimensions were statistically significant and positively related to salesforce performance. Implications were drawn for future research and managerial attention.
\end{abstract}

Keywords: Sales Performance; Sales promotion; Customer Orientation; Supervisory Support; Training.

\section{INTRODUCTION}

Sales performance has been treated and supported as the endogenous, moderator, and mediating variables in the previous literature. The serious efforts to identify and describe the progress of sales in relation to performance. The term sales performance in the SME's relates to the selection of salesperson, interactions with the buyer, job strategy, motivation, and supervision. In today's fast pace world, the prospect for progressing in sales and performance to achieve the goal is high in relation to the training, customer orientation and supervisory behaviors. This will definitely provide a fair understanding of the sales performance domain. 
The best approach to increase the sale performance, however, is to analyze the impact of training, customer-oriented goals and supervisory behavior of an organization and its structural composition. Actually, this is a way that enhance in order to gain motivation and satisfaction to organizational commitment. It is very important to know about the things that included and influenced the sales performance by training and skills development for personnel. This could be functional with the help of the principle of customer orientation goals for the organization. But this also required that exclusive interaction in terms of supervisory behaviors. So, overall, in a general view, we need an attitude that targets and covers the facts of sales performance via impacts of different elements such as training, customer-oriented goals and supervisory behavior of an organization. Constructed on the above argument, this study aims to identify the impact of training, customer-oriented goals, and supervisory behavior of an organization on sale performance of SME's.

\section{RESEARCH QUESTIONS}

Following are the important research questions associated with this study.

- What is the impact of sales training on sales performance?

- What is the impact of customer orientation on sales performance?

- What is the impact of supervisory behavior on sales performance?

\section{OBJECTIVES OF THE STUDY}

The present research is intended to find out impact of different elements on the sales performance. More precisely the following objectives are furnished

- $\quad$ To determine the impact of sales training on sales performance.

- $\quad$ To determine impact of customer orientation on sales performance.

- $\quad$ To determine the impact of supervisory behavior on sales performance.

\section{SIGNIFICANCE OF THE STUDY}

The study endeavored to add understanding and attentiveness about concepts of sales performance. It also subsidized an addition of the elements such as training, customer-oriented goals and supervisory behavior of an organization and its impacts to the sales performance, and 
its influence on SMEs in general. However, the findings of this research will be the helpful for other researchers headed to filling gaps of appropriate literature related to sales performance and SME's.

\section{LIMITATIONS OF THE STUDY}

The limitation of study is that; the findings cannot be generalized to all institutions because it covers only 5 SME's. This research was not entirely capable to gather enough information due to official and data restrictions of the SMEs at Karachi city. Few confidential things were also existing that unable the researcher to get entitled to access. Moreover, this research has some restrictions. First of all, the sample size of this study is small and needed to be increase in order to enhance the level of generalization. Secondly, the data is collected from a specific group of individuals.

\section{LITERATURE REVIEW}

There are many factors that impact sales performance such as sales training, customer-oriented, technology, CRM, and social media. The diffusion of technology, such as customer relationship management (CRM) systems and social media, has created a need to improve the understanding of how to manage interactions with customers in today's digital era. The importance of technology is raised in term of social media and as the world is treated as the "global village'. More importantly beginning of novelties such as cloud computing and webbased technology safe time and human efforts. The term sales performance is the key to success for many organizations and treated as most demanding topic for firms.

\section{Sales Performance}

Sales performance can provide a vital cause of knowledge and obtain the competitive benefit in an organization. The sales capability must enable business to perform well. So, business and especially sales is the link between customer and a firm. The success of an organization is based on the effectiveness of sales and efficiency of salespersons. This concept brings a lots of innovation in describing the processes and strategy to grow in the market. (Román et al., 2002; Rodriguez et al., 2015; Nkanikpo Ibok \& Sunday, 2013).

\section{Sales Training}

Sales performance is directly affected by sales trainings. Basically, sales training comprised on three phases. First stage is the involvement or engagement to the organized endeavor to define, 
second stage is the transfer good to salespeople and third stage is the accumulated feedback or achievement of the salesperson. The utmost purpose of corporate sales training is to bring the increase sales performance. If a customer is more informed it is possible only through the better customer service and reaches towards the expectations. Additionally, the competition raised globally and demand the strong changes which initiate the new and upgraded. Training is a way that enhance on going skill. (Román et al., 2002)

\section{Assessment}

The term assessment is based on the current and available need and objective of an organization. It is based on the changes that is required with the passage of time and challenges. (Román et al., 2002)

\section{Training}

Training is the selection of trainers, trainees, training facilities and a unique strategy that make able to implement some plan and achieve the objectives (Román et al., 2002).

\section{Evaluation}

Evaluation is different from assessment in the facts that it will be taken place at the end of some implemented plan in order to learn or analyze that is achieve through some strategy (Román et al., 2002).

\section{Customer Orientation}

Customer orientation is an attempt that integrate this data into their sales process. It emphases on the understanding and sustaining its customers' necessities bringing excellence and appropriateness and constructing long-term relationships. (Rodriguez et al., 2015)

\section{CRM Effectiveness}

The term CRM is the abbreviation of Customer Relationship Management which relates to the technology and its impact on the customer-oriented approaches. Actually it is based upon the needs of the increasing and productive site of the sales performances (Rodriguez et al., 2015).

\section{Social Media Usage}

Technology is useful tool that bring an increase in the customer relationship and capturing competitive edge in today's life. From technology an organizations want to shape a structure 
that processes to bring value to the customer from tools like LinkedIn, Facebook and blogs (Rodriguez et al., 2015).

\section{Supervisory Behavior}

The supervisor exercising an uninterrupted impact on their subordinates basically compose a central role for motivating/ demotivating their subordinates. It is an important part of sales performance related to its work relationship with workers and provide the influence on large and medium scale businesses. The supervisory attitude significantly contributes to enhance the performance of sales and require a fair understanding with the concept. There is certain effect of the supervisory behaviors on the performance of sales of the employees of SME's. The concept is related to the corporate productivity and creativity, enhancing the workforce organizational performance and commitment. The basic key facts of supervisory is the employee aligned association that result in employee retention and surge future growth of the business ( $\mathrm{Ju}$ et al, 2019; Punyawardena, 2017). The switching behavior is also an important element in relation of the supervisory behavior such as autonomy, compliment, sharing leadership, gratitude, incentive, motivation towards their work and enhance the level of corporation (Akram, Kamran, Iqbal, Habibah, \& Ishaq, 2018) .

\section{Contingent Approving Behavior}

Contingent approving behavior is something that is based on the facts that a supervisor giving recognition or praise in term to his or her subordinates for work which was performed excellently (Ryan, \& Brown, 2003). The praise is the essential that arises and criticizing when performance seem like down because it comprising for best available efforts presented in an employee (Nkanikpo Ibok \& Sunday, 2013).

\section{Upward Influencing Behavior}

In upward influencing behaviors - supervisors attempt to maintain a good rapport between them and their subordinates with the hope that they will act in a way that is favorable to the organization (Fulk \& Wendler, 1982; Nkanikpo Ibok \& Sunday, 2013).

\section{Achievement Oriented Behavior}


The term Achievement oriented behavior is involving with different setting or conditions that challenging objectives for employees and supposing high performance with establishing confidence that employees must achieve that goals (Thomas, 1983; Nkanikpo Ibok \& Sunday, 2013).

\section{THEORETICAL FRAMEWORK}

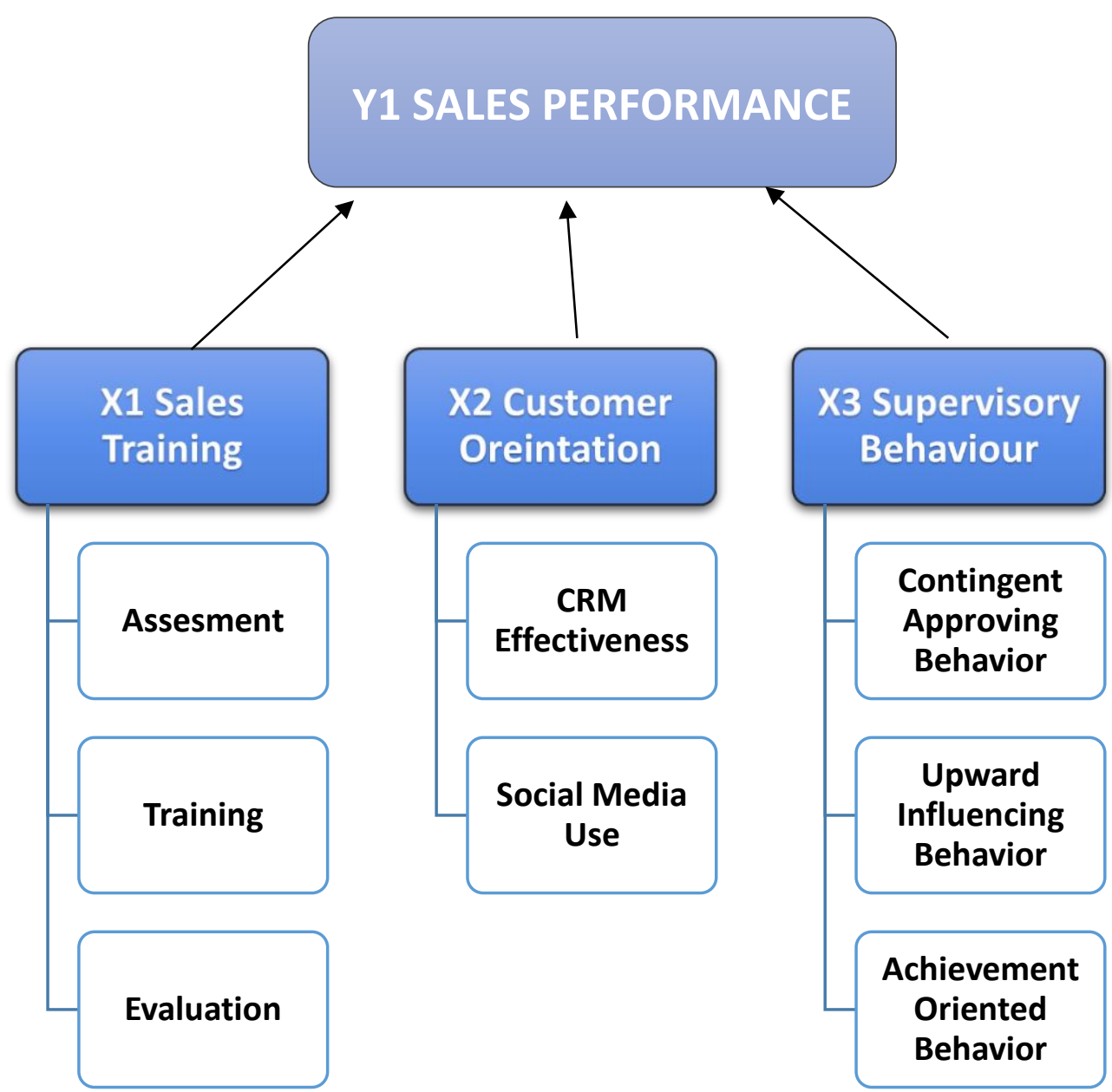

\section{RESEARCH HYPOTHESES}

\section{Null Hypothesis}

$H_{0}$ : Sales training do not have impact on sales performance

$H_{0}$ : Customer orientation do not have impact on sales performance

$H_{0}:$ Supervisory behavior do not have impact on sales performance 


\section{Alternate Hypothesis}

$H_{1}$ : Sales training have impact on sales performance

$\mathrm{H}_{2}$ : Customer orientation have impact on sales performance

$H_{3}$ : Supervisory behavior have impact on sales performance

\section{Variables}

\begin{tabular}{|c|c|c|c|}
\hline $\begin{array}{c}\text { Dependent } \\
\text { Variable }\end{array}$ & $\begin{array}{c}\text { Independent } \\
\text { Variables }\end{array}$ & Sub-Dimensions & $\begin{array}{l}\text { Citation/ } \\
\text { Reference }\end{array}$ \\
\hline \multirow{8}{*}{$\begin{array}{l}\text { Sales } \\
\text { Performance }\end{array}$} & \multirow{3}{*}{$\begin{array}{l}\text { Sales } \\
\text { Trainings }\end{array}$} & Assessment & \multirow{3}{*}{$\begin{array}{l}\text { (Román et al., } \\
\text { 2002) }\end{array}$} \\
\hline & & Trainings & \\
\hline & & Evaluation & \\
\hline & \multirow{2}{*}{$\begin{array}{l}\text { Customers } \\
\text { Orientation }\end{array}$} & CRM Effectiveness & \multirow{2}{*}{$\begin{array}{l}\text { (Rodriguez et al., } \\
2015 \text { ) }\end{array}$} \\
\hline & & Social Media Use & \\
\hline & \multirow{3}{*}{$\begin{array}{l}\text { Supervisory } \\
\text { Behavior }\end{array}$} & Contingent Approving Behavior & \multirow{3}{*}{$\begin{array}{l}\text { (Nkanikpo Ibok } \\
\& \text { Sunday, 2013) }\end{array}$} \\
\hline & & Upward Influencing Behavior & \\
\hline & & Achievement Oriented Behavior & \\
\hline
\end{tabular}

\section{RESEARCH METHODOLOGY}

The paper projected to search the impact of training, customer-oriented goals and supervisory behavior of an organization and its impacts to the sales performance employee working in SME's Karachi.

\section{Research Design}

The present study was conducted by survey approach in term of descriptive research method. Mix model of research is used for collecting data. Through this survey method extraneous variables are eliminated. This research adopted quantitative research method. The research design was chosen due to flexibility in terms like in-depth and holistic investigation.

The present study was conducted by descriptive research method. Descriptive research is a research method that defines some unique characteristics/ phenomena of the population for 
study. This practice more emphases on the "what" element of the study subject relatively than the "why" element of the research subject (QuestionPro, n.d.). Similarly, this research follows the basic research features that includes the interest and need to enlarge the understanding purely determined by curiosity. It does not tend to be directly valid to the real world in a real setting but improves understanding different phenomenon of the world.

\section{Research Technique}

The way of gathering research data was the Primary sources which is collected by a researcher through questionnaire methods like surveys. This information is utilized for the first time as the researcher collected and involved in analysis (Cresswell, 1999). It also includes the Secondary sources such as research article, website data and available literature in previous research.

\section{Research Approach}

This research is based on the deductive approach. It was started with a hypothesis on the basis of the available literature, collected data according and finally trial the data for implementation. This supports the objectives from more general level to a more specific one. Cross-sectional surveys are observational surveys conducted in such conditions because the researcher means to gather data from a sample of the target population in given time (Sedgwick, 2014; Levin, 2006). Similarly, the type of investigation for research was chosen as correlational. This research study is based on the subjectivity in which an individual's feelings and views are originally addressed. It also eliminates the elements of the restriction and based on the natural settings.

\section{Population and Sample}

Population for this study has been chosen from the employee working in SMEs in Karachi. Self-explanatory questionnaires were circulated to collect the data from the participants. From non-probability sample the Purposive sampling was selected in order to collect the data. Only 5 SMEs were selected for sampling. From all these SMEs 50 respondents was selected. 


\begin{tabular}{|c|c|}
\hline \multicolumn{2}{|l|}{ Population } \\
\hline Male & Female \\
\hline $37(74 \%)$ & $13(26 \%)$ \\
\hline \multicolumn{2}{|l|}{ Experience } \\
\hline Less than 3 years & More than 3 years \\
\hline $22(44 \%)$ & $28(56 \%)$ \\
\hline \multicolumn{2}{|l|}{ Qualification } \\
\hline Graduation & Masters and Higher \\
\hline $31(62 \%)$ & $19(38 \%)$ \\
\hline
\end{tabular}

This study defines using a sample of employee of SME's, a single SME's employee was treated as a sampling unit. A sample size of 50 was selected for the study from the SMEs in Karachi. The purposive sampling technique was selected in order to get the sample that judge purely allow to collect the data for the purpose of study and create understanding of target population (Bhat, n.d.).

\section{Instrumentation and Data Collection}

Questionnaire was used as the data collection instrument and comprised of close-ended questions. It was divided into four segments: The first part was designed to analyze demographic data. In second, part it collects data on sales performance. The third part was based on the training and forth part includes the items related to customer orientation while fifth comprises of the items related to supervisory behavior. The data was analyzed by using the IBM SPSS Statistics software. 
Variables

\begin{tabular}{|c|c|c|c|}
\hline Variables & $\begin{array}{c}\text { Sub- } \\
\text { Dimensions }\end{array}$ & Item List & $\begin{array}{l}\text { Citation/ } \\
\text { Reference }\end{array}$ \\
\hline $\begin{array}{l}\text { Sales } \\
\text { Performance }\end{array}$ & & $\begin{array}{l}\text { 1. Sales is the basic function of the organizations. } \\
\text { 2. Sales performance depend upon the training of } \\
\text { the employee. } \\
\text { 3. Sales is affected by the technology. }\end{array}$ & $\begin{array}{l}\text { (Román et al., } \\
\text { 2002)(Rodriguez } \\
\text { et al., } \\
\text { 2015)(Nkanikpo } \\
\text { Ibok \& Sunday, } \\
\text { 2013) }\end{array}$ \\
\hline \multirow[t]{3}{*}{$\begin{array}{l}\text { Sales } \\
\text { Trainings }\end{array}$} & Assessment & $\begin{array}{l}\text { 1. Sales performance is directly affected by sales } \\
\text { trainings. } \\
\text { 2. Assessment is needed to analyze the need. } \\
\text { 3. Well-defined goals enable to achieve in clear } \\
\text { manner. } \\
\text { 4. Assessment appreciate the progress. }\end{array}$ & \multirow[t]{3}{*}{$\begin{array}{l}\text { (Román et al., } \\
\text { 2002) }\end{array}$} \\
\hline & Trainings & $\begin{array}{l}\text { 1. Training is a way that enhance on going skill. } \\
\text { 2. It appreciate the new learning and experience. }\end{array}$ & \\
\hline & Evaluation & $\begin{array}{l}\text { 1. The competition raised globally demand rapid } \\
\text { evaluation which initiate the new and upgraded } \\
\text { techniques. }\end{array}$ & \\
\hline \multirow[t]{2}{*}{$\begin{array}{l}\text { Customers } \\
\text { Orientation }\end{array}$} & $\begin{array}{l}\text { CRM } \\
\text { Effectiveness }\end{array}$ & $\begin{array}{l}\text { 1. Customer orientation is an attempt that } \\
\text { integrate this data into their sales process. } \\
\text { 3. Its emphases on the understanding and } \\
\text { sustaining its customers' necessities. } \\
\text { 3. It is source of bringing excellence and } \\
\text { appropriateness and constructing long-term } \\
\text { relationships. }\end{array}$ & \multirow[t]{2}{*}{$\begin{array}{l}\text { (Rodriguez et } \\
\text { al., 2015) }\end{array}$} \\
\hline & $\begin{array}{l}\text { Social Media } \\
\text { Use }\end{array}$ & $\begin{array}{l}\text { 1. Social media is equally important for sales } \\
\text { generation. } \\
\text { 2. It is the basic need of the technology. }\end{array}$ & \\
\hline
\end{tabular}




\begin{tabular}{|c|c|c|c|}
\hline & & $\begin{array}{l}\text { 3. It brings additional advantages such as time } \\
\text { saving. }\end{array}$ & \\
\hline Supervisory & Contingent & 1. Supervisor giving recognition or praise in term & \multirow{5}{*}{$\begin{array}{l}\text { (Nkanikpo Ibok } \\
\text { \& Sunday, } \\
\text { 2013) }\end{array}$} \\
\hline \multirow[t]{4}{*}{ Behavior } & Approving & to his or her subordinates for work. & \\
\hline & Behavior & $\begin{array}{l}\text { 2. Employee receive critics when performance } \\
\text { seem like down. }\end{array}$ & \\
\hline & $\begin{array}{l}\text { Upward } \\
\text { Influencing } \\
\text { Behavior }\end{array}$ & $\begin{array}{l}\text { 1.The supervisor have a direct influence in either } \\
\text { motivating or demotivating their subordinates. } \\
\text { 2. Supervisory Behavior is a fundamental element } \\
\text { of work performance in the SME's. }\end{array}$ & \\
\hline & $\begin{array}{l}\text { Achievement } \\
\text { Oriented } \\
\text { Behavior }\end{array}$ & $\begin{array}{l}\text { 1. Achievement oriented behavior is involving } \\
\text { with different setting. } \\
\text { 2. It provides challenging objectives for } \\
\text { employees. } \\
\text { 3. It expects the high performance with } \\
\text { establishing confidence. }\end{array}$ & \\
\hline
\end{tabular}

\section{ETHICAL CONSIDERATIONS}

The following ways will address how participants were protected.

- $\quad$ There must an Informed consent for the voluntary participation of the employee and

- $\quad$ The aspect of anonymity and secrecy must be maintained.

\section{DATA ANALYSIS AND RESULTS}

The data was analyzed by using Pearson's correlation the IBM SPSS Statistics software. Researchers analyze the collected data through the questionnaire tools. Data analysis involves dropping gathered data to a handy size, summary, patterns, and applying various statistical techniques. 


\section{Descriptive Statistics}

This study used statistical methods to analyze data that is, descriptive statistics in term of measures of central tendency including mean, mode, and median, and measures of dispersion which will include, standard deviation and variance.

\section{Inferential Statistics}

Inferential statistics were also used to draw inferences about the population from a sample as well as conduct statistical tests of correlation. Statistical Package for Social Scientists (SPSS) version 21 was used to facilitate the data analysis.

\section{Hypothesis Assessment Summary}

\section{$H_{0:} \quad$ Sales training do not have impact on sales performance.}

A Pearson correlation analysis was performed at significance level of $\mathrm{p}=0.01$ using SPSS to test the hypothesis. A Pearson coefficient with respect to sales performance is 0.235 (Sales training). It is observed that the sales trainings have positive correlation with sales performance, and it is statistically significant. This means that null hypothesis cannot be accepted. It proves that SME's sales training has positive relationship with the sales performance. As null hypothesis cannot be accepted, the following alternative describes the relationship between sales training do not have impact on sales performance.

\section{H1: Sales training have impact on sales performance.}

Training intensify the salesman's understanding base and apt level, resulting in high sales performance. The best trainings provide the chances for speed up the sales performance.

\section{Ho: $\quad$ Customer orientation do not have impact on sales performance}

A Pearson correlation analysis was performed at significance level of $\mathrm{p}=0.01$ using SPSS to test the hypothesis. A Pearson coefficient with respect to sales performance is 0.346 (customer's orientations). It is observed that the customer orientation has positive correlation with sales performance, and it is statistically significant. This means that null hypothesis cannot be accepted. It proves that SME's customer-oriented activities have positive relationship with 
sales performances. As null hypothesis cannot be accepted, following alternative describes the customer orientation relationship with sales performance.

\section{$\mathrm{H}_{2}$ : Customer orientation have impact on sales performance}

Customer's orientation is a way that capability and helps SME's organization to systematically translate its plans and strategies into the final outcome and enhance she sales activities. Proper allocation of all available resources is necessary for better and systematic accomplishment of customer-oriented approach.

\section{$H_{0}:$ Supervisory behavior do not have impact on sales performance}

A Pearson correlation analysis was performed at significance level of $\mathrm{p}=0.01$ using SPSS to test the hypothesis. A Pearson coefficient with respect to sales performance is 0.346 (supervisory behavior). It is observed that the supervisory behavior has positive correlation with sales performance, and it is statistically significant. This means that null hypothesis cannot be accepted. It proves that SME's supervisory behavior has positive relationship with sales performances. As null hypothesis cannot be accepted, following alternative describes supervisory behavior with sales performances.

\section{$\mathrm{H}_{3}:$ Supervisory behavior have impact on sales performance}

Supervisory behavior is treated as the basic element for the sales performance supervision and its turn the objective in the reality and final outcome.

\section{DISCUSSION AND CONCLUSION}

\section{Discussion}

This study delivers several contributions such as the effectiveness of the training, CRM, Social media, and supervisory behavior on the sales performances. As the previous studies states these 3 concepts have positive relation with the sales performances and it can be said that the sales performance can highly affected by training, CRM, Social media, and supervisory behavior. Training intensify the salesman's understanding base and apt level, resulting in high sales performance. The best trainings provide the chances for speed up the sales performance. Customer's orientation is a way that capability and helps SME's organization to systematically 
translate its plans and strategies into the final outcome and enhance she sales activities. Proper allocation of all available resources is necessary for better and systematic accomplishment of customer-oriented approach. Supervisory behavior is treated as the basic element for the sales performance supervision and its turn the objective in the reality and final outcome.

\section{Conclusion}

A Pearson correlation analysis was performed at significance level of $\mathrm{p}=0.01$ using SPSS to test the hypothesis. A Pearson coefficient with respect to sales performance is 0.235 (Sales training). It is observed that the sales trainings have positive correlation with sales performance, and it is statistically significant. A Pearson correlation analysis was performed at significance level of $\mathrm{p}=0.01 \mathrm{using}$ SPSS to test the hypothesis. A Pearson coefficient with respect to sales performance is 0.346 (customer's orientations). It is observed that the customer orientation has positive correlation with sales performance, and it is statistically significant. A Pearson correlation analysis was performed at significance level of $\mathrm{p}=0.01$ using SPSS to test the hypothesis. A Pearson coefficient with respect to sales performance is 0.346 (supervisory behavior). It is observed that the supervisory behavior has positive correlation with sales performance, and it is statistically significant.

\section{RECOMMENDATIONS AND FUTURE DIRECTIONS}

The findings of this research also recommend the attention in future towards the various elements of sales performance for future researchers by diving deeper and changing the potential of other moderating such as the technology, the competency of salesmen's, size and structure of the organization or other related variables. This research may also test with different sectors or industry to analyze the different settings. 


\section{REFERENCES}

Akram, A., Kamran, M., Iqbal, M. S., Habibah, U., \& Ishaq, M. A. (2018). The impact of supervisory justice and perceived Supervisor support on organizational citizenship behavior and commitment to supervisor: the mediating role of trust. Cogent Business \& Management, 5(1), 1493902.

Creswell, J. W. (1999). Mixed-method research: Introduction and application. In Handbook of educational policy (pp. 455-472). Academic press.

Fulk, J., \& Wendler, E. R. (1982). Dimensionality of leader-subordinate interactions: A path-goal investigation. Organizational Behavior and Human Performance, 30(2), 241-264.

Ju, D., Huang, M., Liu, D., Qin, X., Hu, Q., \& Chen, C. (2019). Supervisory consequences of abusive supervision: An investigation of sense of power, managerial self-efficacy, and task-oriented leadership behavior. Organizational Behavior and Human Decision Processes, 154, 80-95.

Levin, K. A. (2006). Study design III: Cross-sectional studies. Evidence-based dentistry, 7(1), 24-25.

Nkanikpo Ibok, I., \& Sunday, V. (2013). Impact of Supervisory Behaviours on Sales force Performance: The Case of Micro Finance Banks. In Journal of Economics and Sustainable Development www.iiste.org ISSN (Vol. 4, Issue 3). Online. www.iiste.org

Punyawardena, W. (2017). Influence of supervisory behavior on job satisfaction among university library assistants in Sri Lanka.

Rodriguez, M., Peterson, R. M., \& Ajjan, H. (2015). Crm/Social Media Technology: Impact on Customer Orientation Process and Organizational Sales Performance. In Ideas in Marketing: Finding the New and Polishing the Old (pp. 636-638). Springer International Publishing. https://doi.org/10.1007/978-3-319-10951-0_233

Román, S., Ruiz, S., \& Luis Munuera, J. (2002). The effects of sales training on sales force activity. European Journal of Marketing, 36(11/12), 1344-1366. https://doi.org/10.1108/03090560210445218

Ryan, R. M., \& Brown, K. W. (2003). Why we do not need self-esteem: On fundamental needs, contingent love, and mindfulness. Psychological inquiry, 14(1), 71-76. 
Sedgwick, P. (2014). Cross sectional studies: advantages and disadvantages. Bmj, 348 .

Thomas, E. A. (1983). Notes on effort and achievement-oriented behavior. Psychological Review, 90(1), 1. 


\section{APPENDIX}

\section{Questionnaire}

Age:

Gender:

Experience:

Qualifications:

Kindly answer by tick mark in the given boxes below were:

$\mathrm{SDA}=$ Strongly Disagree, $\mathrm{D}=$ Disagree, $\mathrm{N}=$ Neutral, $\mathrm{A}=$ Agree, $\mathrm{SA}=$ Strongly Agree

\begin{tabular}{|c|c|c|c|c|c|c|}
\hline S.NO & ITEMS & $\begin{array}{l}\text { SD } \\
\text { A }\end{array}$ & DA & $\mathbf{N}$ & $\mathbf{A}$ & SA \\
\hline 1. & Sales is the basic function of the organizations. & & & & & \\
\hline 2. & Sales performance depends upon the training of the employee. & & & & & \\
\hline 3. & Sales is affected by the technology. & & & & & \\
\hline 4. & Sales performance is directly affected by sales trainings. & & & & & \\
\hline 5. & Assessment is needed to analyze the need. & & & & & \\
\hline 6. & Well-defined goals enable to achieve in clear manner. & & & & & \\
\hline 7. & Assessment appreciate the progress. & & & & & \\
\hline 8. & Training is a way that enhance on going skill. & & & & & \\
\hline 9. & It appreciate the new learning and experience. & & & & & \\
\hline 10. & $\begin{array}{l}\text { The competition raised globally demand rapid evaluation which } \\
\text { initiate the new and upgraded techniques. }\end{array}$ & & & & & \\
\hline 11. & $\begin{array}{l}\text { Customer orientation is an attempt that integrate this data into } \\
\text { their sales process. }\end{array}$ & & & & & \\
\hline 12. & $\begin{array}{l}\text { Its emphases on the understanding and sustaining its customers' } \\
\text { necessities. }\end{array}$ & & & & & \\
\hline
\end{tabular}




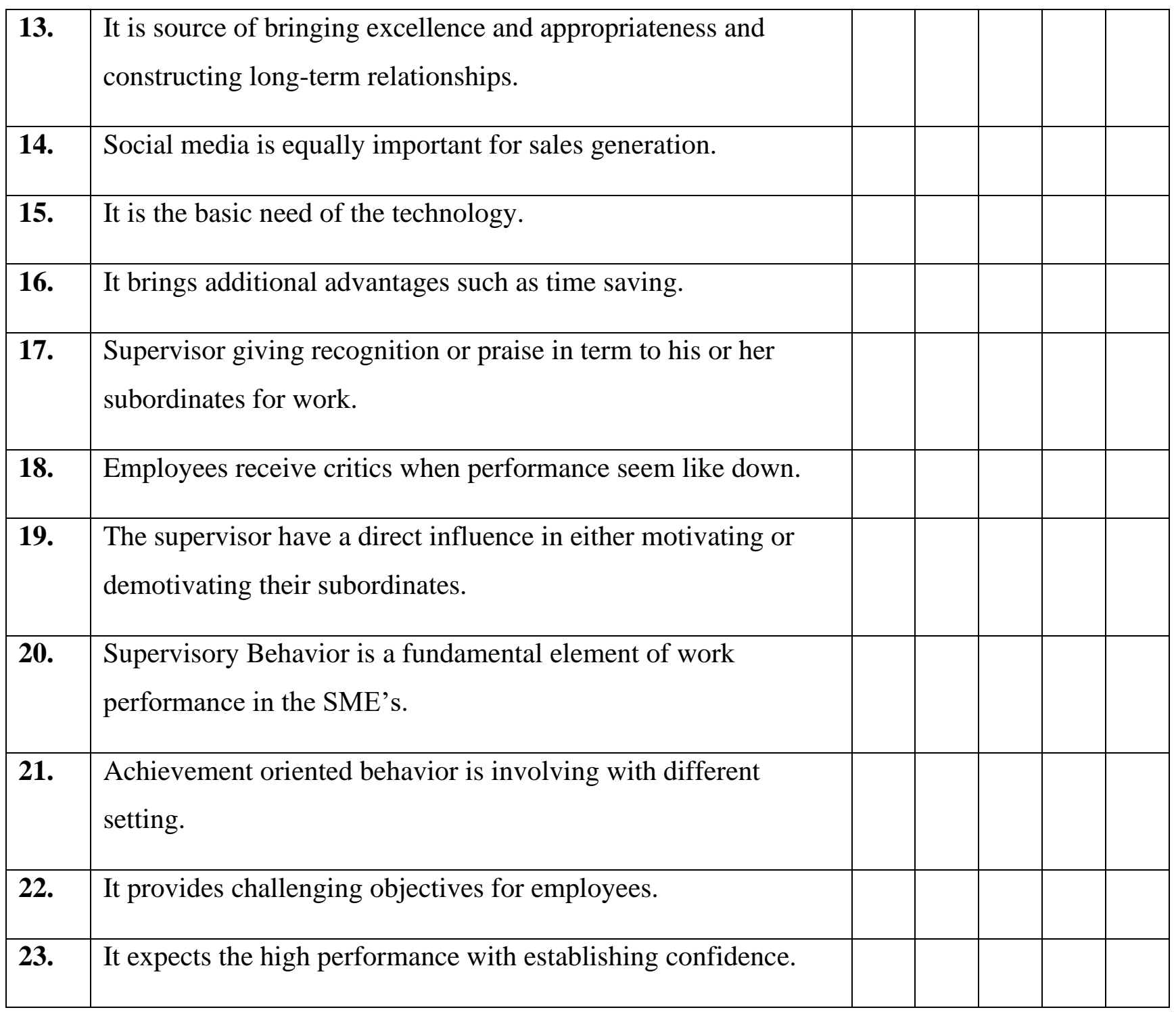

